\title{
Female Identity and Storytelling in Louise Erdrich's Tracks and Amy Tan's The Joy Luck Club
}

\author{
Mar Gallego \\ Universidad de Huelva
}

Within the main concerns of contemporary feminist criticism, the construction of female identity deserves utmost attention and analysis, since a profound revision of the social and sexual parameters that ground such construction is deemed imperative. Both novels-Louise Erdrich's Tracks (1988) and Amy Tan's The Joy Luck Club (1989)-tackle this issue of the construction of female identity challenging and subverting conventional views of femininity that spring from two very different traditions: Native American and Chinese American cultures respectively. The similarities and differences that can be inferred from a comparative study of both novels thus problematise the traditional standpoint which defines femininity according to two opposite codes that coexist in each of the cultures under scrutiny: Native or Chinese and an alien value system, that of the Western culture.

Concurrently, the comparison drawn from these texts highlights the articulation of means of active resistance to both codes because externally imposed and therefore basically based on both racial and sexual prejudice. The most suitable instrument to engage in active resistance is storytelling, which foregrounds the double purpose of these two novels: on the one hand, a complete rejection of any biased preconception of femininity and on the other, an attempt to assert a self-defined and self-constructed concept of female identity. The protagonists need to tell their own stories in order to break away from conventional images or stereotypes of womanhood exposing their racist and sexist innuendo, thus providing the necessary clues to finally rediscovering their true female selves.

In the case of Tracks, the significance of storytelling is stressed from the beginning of the novel, since to tell stories means literally to survive for Nanapush, one of the two narrators of this text, who saves his own life by means of talking: "I got well by talking" (46). Nanapush is one of the few survivors from the terrible winter of 1912, in which the Chippewa tribe is almost exterminated due to a combination of illnesses and bitter weather. $\mathrm{He}$ then takes on the responsibility of telling Lulu, his adopted granddaughter, her mother's story, which is really the story of their tribe, because as he readily admits, all stories are "... attached, and once I start there is no end to telling because they're hooked from one side to the other, mouth to tail" (46). Therefore to tell stories becomes a means of ensuring survival and continuance for the community, because they connect back to the tribal past through retelling the story of Lulu's mother, Fleur, and establish a necessary link with the future represented by Lulu. Three generations-Nanapush as adopted grandfather, Fleur as mother and Lulu as daughter — are thus united through the mythical power of storytelling. 
Obviously, what stands out in this line is the fact that Nanapush acts as a storyteller, while in Native American tradition this role is usually assumed by a grandmother. ${ }^{1}$ On the one hand, he can be explained as intimately linked to the trickster figure of Nanabush, as Brehm has pointed out. ${ }^{2}$ In this primary mythical definition Nanapush is also the representative of tradition, insofar as he reiterates once and again the importance of maintaining the connection to tradition as vital nurturing for the community. As Brehm goes on stating, "Nanapush . . . attempts to talk Lulu . . . back into traditional culture" (694), recovering for her any lost links to her mother, and through her to the traditional way of life, recreating the world for her as his mythical counterpart would do. This recreation for Lulu's benefit also signifies the only possibility left for the Chippewas to preserve their heritage intact and, consequently, their tribal identity in the face of change and disintegration.

But Nanapush's role as a male storyteller who hands down tradition to future female generations could be also interpreted as Erdrich's attempt to upset the ruling patriarchal order and graphically stage the return to a lost gynocracy, characteristic of Native American cultures before Western colonization, ${ }^{3}$ since Nanapush ensures continuation for the Chippewa way of life through a matrilineal line, choosing to tell Fleur's story and adopting Lulu as his alleged granddaughter and intended audience. In this sense, Nanapush through his storytelling actively rejects conventional views of womanhood coming from both Native and Western sources, and attempts to redefine, to reinvent a positive image of Native women as powerful and essential members of the Chippewa community.

The same holds true of the women narrators of the Joy Luck Club, who through their stories articulate a newly-found sense of identity that challenges any previous notions of womanhood. In this novel storytelling also serves to ensure survival, since the four mothers of the text need to tell their stories in order to continue living and, especially, to continue hoping, which was the main purpose of the foundation of the Joy Luck Club back in China:

We weren't allowed to think a bad thought. We feasted, we laughed, we played games, lost and won, we told the best stories. And each week, we could hope to be lucky. (25)

Telling stories becomes then the only means to physically survive and confront pain both in China and on their arrival to the United States, where they encounter racism and discrimination on an everyday basis.

Moreover, storytelling also ensures continuation with the past, since it connects the mothers' past in China to their daughters' lives in America. The four mothers constantly engage in telling their stories to their daughters to fill the gap between present and past generations, so they are "of necessity storytellers and even historians" (Foster 210). In this

\footnotetext{
${ }^{1}$ Paula Gunn Allen asserts the crucial role of grandmothers as storytellers and central figures to Native American traditions in The Sacred Hoop (1986).

${ }^{2}$ Brehm refers to the Algonquian creation texts in which a trickster figure, known by different names, makes use of his cunning and his trickster abilities to successfully kill Misshepeshu, a lake divinity, and then recreates the world, but his victory does not last long, since Misshepesu is immortal and comes back to life to reestablish communal order (683-4).

${ }^{3}$ In The Sacred Hoop Allen engages in a rediscovery of Native American tribal history, in which she emphasizes the gynocratic system that almost all tribes upheld prior to the sixteenth century and the effect of the processes of colonization and christianization which actually implied the passage from matriarchal to patriarchal rules.
} 
way, the mothers are trying to relate to their daughters handing down to them their experiences, their ideas and their traditions, so their stories ". . . become a way to bridge the generational and cultural gap" (Boter 147). A clear illustration of the trascendence and meaning the mothers assign to their stories can be seen when Jing-Mei Woo is encouraged to visit her sisters in China and tell them about their mother who has recently passed away:

Tell them stories of your family here. How she became success. . . Tell them stories she told you, lessons she taught, what you know about her mind that has become your mind. (40)

In this passage the mothers are targeting at what seems to be the main motivation behind their stories, their main hope: to pass on to their daughters their cultural legacy establishing a direct psychic link with them that allows for mutual understanding.

Despite the constant efforts on the mothers' part, this connection is problematic, since the daughters do not fully understand their mothers, as Jing-Mei acutely observes: "In me, they see their own daughters, just as ignorant, just as unmindful of all the truths and hopes they have brought to America" (40). Their problems of communication stem from the fact that they speak two different languages-Chinese for the mothers and English for the daughters - but even more from the daughters' attitudes that dismiss their mothers' stories as "Chinese superstitions" (31) or "a Chinese fairy tale" (25). Mothers realise they are losing their daughters and themselves, as Ying-Ying St. Clair exemplifies in the following quote: "We are lost, she and I, unseen and not seeing, unheard and not hearing, unknown by others" (67), but they are determined to fight back and reclaim their and their daughters' lost identities. Therefore, storytelling becomes for the mothers the only available vehicle to both find their true selves and achieve reconciliation with their daughters, counteracting the negative influence of demeaning images of women that spring from both Chinese and American cultures. As Nanapush's, the main objective of the mothers' stories can be understood as a decisive rejection of conventional notions of femininity and a search for alternative modes for self-definition.

Resisting unflattering stereotypes is thus one of the main aims of the use of storytelling in both novels, due to the fact that they convey an image of womanhood at odds with the positive sense of identity that the two authors propound. Erdrich as well as Tan forcefully focus their narratives on an extensive critique on conventional definitions of feminine identity informed by Western patriarchal notions of inferiority/superiority and gender roles. In both cases, such critique also pays attention to traditional representations of women in the culture of origin - Native and Chinese respectively - to highlight similarities and differences in order to complete the cultural mapping of the legacy that these women must come to grips with in order to reconstruct a suitable and fulfilling sense of female identity. In this sense, both authors acknowledge the crucial role of image-making and image-controlling for these two groups of ethnic women. ${ }^{4}$

\footnotetext{
${ }^{4}$ One of the main interests of current ethnic writing is precisely the analysis of the role played by processes of image-formation in the search for a functioning sense of identity in ethnic groups and who exerts the control over such processes becomes undoubtedly a key issue to struggle with. See Bell Hooks' enlightening study on this topic in Black Looks.
} 
As far as Native American women are concerned, the importance of the control of this process is aptly recognized by Allen:

Image casting and image control constitute the central process that American Indian women must come to terms with, for on that control rests our sense of self, our claim to a past and to a future that we define and we build. (192)

Allen's words clearly pinpoint at the profound implications that images possess in the contemporary world as a means of self-definition and resistance for Native American women, and by extension, for all ethnic women. The active ways in which these women get involved in the process of image-making disavow any imposed external definitions, calling into question the very parameters on which they are based and the internalization processes that usually accompany their success.

Thus Native American women have almost been non-existent through centuries of forgetfulness and dominance of male images of fiendish and cruel savages. If anything, they have generally been perceived from the Western standpoint as weak, insecure, prone to drinking and sex excesses and inevitably self-destructive. One could argue that all these features correspond to any description of Native Americans in general proposed by the dominant culture, but they particularly apply to women, since in their case both racial and sexual prejudice intertwine. They are furthermore objectified as white man's sexual partners, willing or not, as the story of Western colonization sharply shows, whose "civilizing effect" Allen ironically denounces. ${ }^{5}$

But apart from the Western legacy of pervasive objectification and dehumanization, Native American women must deal with their own culture, and this double allegiance makes them ". . . suffer from the societal conflicts caused by having to identify with two hopelessly opposed cultural definitions of women" (Allen 49). This in-between position creates an uneasiness in Native American women that need to reconcile both cultures, going back to their tribal roots in order to rediscover positive representations of women. Thus the Native tradition serves as the foundational stone for the reconstruction of a functioning and satisfactory sense of identity, grounded on images of powerful and strong women who defy patriarchal categorization and play a crucial role in the tribal system.

This is exactly the case in Tracks, where Fleur serves as a potent revulsive against conventional stereotyping of Native women. Fleur's story reconstructs her life from childhood onwards, attesting to her victimization at the hands of three white men who raped her because of her ability at cards. The first interesting twist of the traditional victimization tale is that Fleur is able to take revenge on these men, who actually freeze to death trapped during a storm, and from this moment the gossip spread: "Fleur had enticed the men to her and then killed them for amusement" (55). Fleur is then described as a dangerous seducer who acts as a mysterious, self-reliant and independent being from the rest of the tribe that lives in the middle of the forest, on her family's land. So Fleur is criticized precisely for violating

\footnotetext{
${ }^{5}$ Allen reconstructs in The Sacred Hoop the way in which the colonization and christianization processes meant loss of status for women in the tribes and this devaluation brought about the increase of any kind of violence against them, including rape, battering, etc., typical diseases of a patriarchal order.
} 
the sexist code imposed onto women who are objects of abuse and never subjects that implement self-defence, and freely choose their sexual partners.

But from the Native standpoint, Fleur represents much more than a rebellious woman, she stands for the whole of the Chippewa and Native culture, for as Nanapush puts it, "she was the funnel of our history" (178). At a literal level, she is trying to protect the tribal land and save it from the rapid advance of white civilization, but metaphorically she is protecting the traditional way of life, especially the endurance of their myths and rituals, since Fleur enacts them through her shamanistic powers and her relation to Missepeshu, the lake monster: "She was the one who closed the door or swung it open. Between the people and the gold-eyed creature in the lake ... Fleur was the hinge" (139). This closeness between Fleur and the monster signals her adherence to the natural order of things that all shamans share and her revitalizing of traditional myths for her people's benefit.

In fact, her status as a medicine woman in intimate contact with the forces of nature makes her stand out as the power of femininity itself "in its connection to nature, birth, and the survival of the people" (Shaddock 112). In this sense, Fleur personifies the necessary bond to the ancestral female goddesses that populate the Native American spiritual world, providing the missing link between the Chippewa people and their traditions. This centrality of feminine power dates back to the gynocratic societies that existed in America prior to colonization, in which the female principle was much more than just fertility or maternity, it was the main basis for all creation and all thought. ${ }^{6}$ Filling the gap between past and present, Fleur becomes a new prototype for Native American women, inaugurating a recovery and revisioning of ancestral traditions, in which women held the most distinguished positions within a matriarchal framework.

A sense of matriarchy is also indicated in Tan's novel through a reworking of traditional stereotypes coming from both Western and Chinese traditions. In this case both cultures uphold a patriarchal order, so the stereotypical images of women are very similar in their intent and purpose of objectifying and oppressing women. The main features that characterize such "controlling images," using Patricia Hill Collin's coinage, are passivity, weakness, silence, politeness and indirect in speech among the most recurrent ones. From this brief overview the striking parallelisms with Native American women's stereotypes are noticeable, concretely the emphasis on drawing pictures of weak, hopeless women, in need of male support. But the similarities hold even with regards to the sexual field, since Chinese women are also considered the white man's possession and toy. Indeed, the sexual component is probably more accentuated in the case of Chinese women, since they are seen as the two extremes: either as the so-called "Geisha or China doll" or as its exact counterpart, the "Dragon Lady." According to Espiritu, this twofold dichotomy responds to a need felt by the white patriarchy to assert direct control over Asian women, as the two stereotypes

\footnotetext{
${ }^{6}$ For an accurate account of the meaning and import of the female principle, see "Grandmother of the Sun: Ritual Gynocracy in Native America" in Allen's The Sacred Hoop (13-29), in which Allen details the powerful role of a female cosmology in Native American tribes, where the goddesses- known as Spider Woman, Serpent Woman or Thouught Woman-are the actual centers of thought and power in gynocratic societies.
} 
... eroticize Asian women as exotic 'others' - sensuous, promiscuous, but untrustworthy. Whereas American popular culture denies 'manhood' to Asian men, it endows Asian women with an "excess of womanhood," sexualizing them but also impugning their sexuality. (93)

So they are classified as either the perfect embodiment of womanhood for patriarchal taste, which implies that these women are submissive and especially have no voice, "nonlanguage" (94) as Espiritu calls it; or they are depicted as the symbol of the castration that lurks in the air as a real danger and challenge to patriarchal authority. Either the perfect angel or the prostitute. ${ }^{7}$

Such caricaturing is shared to a great extent by Chinese traditional culture, in which women are categorized as inferior to men, whole role is restricted to comply with men's wishes, the father's or the husband's. ${ }^{8}$ Submissiveness and silence are also greatly praised in conventional rendering of women, mere ornaments with no right to voice or decisionmaking. And it is precisely the patriarchal insistence on lack of voice and passivity which prompt Chinese American women to raise and claim their rightful voice and space, demonstrating the power of their narratives ". . . to both express the realities of our oppression and ... remythologize women's cultural identity in terms of an empowered and recalcitrant subjectivity" (Shaddock 108). Both mothers and daughters tell their own stories in order to refute conventional images of their womanhood and found a sense of identity based on selfrespect and self-reliance.

This is actually the main message mothers try to convey to their daughters. Mothers attempt to build up their daughters' self-esteem, bridging the gap between the two generations in order to achieve some kind of reconciliation. By the end of the novel daughters will be portrayed as coming to terms with their mothers' spiritual and cultural heritage, in some cases returning to China to unite the family, in others finally understanding the meaning behind the mothers' words:

And really, I did understand finally. Not what she had just said. But what had been true all along. I saw what I had been fighting for: It was for me, a scared child, who had run away a long time ago to what I had imagined was a safer place. (183)

The daughters are finally able to understand their mothers' stories and their imbedded message of love and encouragement, and therefore a sense of a reestablished matriarchal harmony is detected in the closing image of the text, where June meets her sisters for the first time and "together we look like our mother" (288).

The same could be ascertained of the end of Tracks, in which Lulu is reclaimed back from the government school by Nanapush. Although Fleur has left the reservation defeated by the white bureaucratic system, Nanapush uses exactly that system for Lulu's benefit: "To become a bureaucrat myself was the only way that ... I could find a ledge to kneel to, to reach through the loophole and draw you home" (225). Employing the white methods,

\footnotetext{
${ }^{7}$ About images of Asian women and their influence in the process of identity formation, see also Mary Young's Mules and Dragons.

${ }^{8}$ Walter Shear explores at length the role of women in Chinese culture and the way in which these limitations affect the lives of the four mothers in "Generational Difference and the Diaspora in The Joy Luck Club".
} 
Nanapush makes a clear statement deconstructing the established order from within and firmly setting the bases for the continuation of the matriarchal line and, as a consequence, of the Chippewa tribe. The ultimate prevailing of positive images of womanhood in both Erdrich and Tan indicates their support to a return to a matriarchal worldview, in which the significance of women can be justly acknowledged.

\section{WORKS CITED}

Allen, Paula Gunn. The Sacred Hoop. Boston: Beacon Press, 1986.

Boter, Babs. "'The Great Power of my Mother Talking-Story': Ethnicity and Identity in the Works of Amy Tan and Maxine Hong Kingston." Multiculturalism and the Canon of American Culture. Ed. Hans Bak. Amsterdam: VV UP, 1993: 146-59.

Brehm, Victoria. "The Metamorphoses of an Ojbwa Manido." American Literature 68.4 (December 1996): 677-706.

Erdrich, Louise. Tracks. New York: Henry Holt and Company, 1988.

Espiritu, Yen Le. Asian American Women and Men. Thousand Oaks: Sage, 1997.

Foster, Marie Booth. "Mother-Daughter Relationships in Amy Tan's The Joy Luck Club and the Kitchen God's Wife." Women of Color. Ed. Elisabeth Brown. Austin: U of Texas P, 1996: 208-27.

Hooks, Bell. Black Looks. Boston: South End Press, 1992.

Shaddock, Jennifer. "Mixed Blood Women: The Dynamic of Women's Relations in the Novels of Louise Erdrich and Leslie Silko." Feminist Nightmares. Eds. Susan Weisser and Jennifer Fleischer. New York: New York UP, 1994: 106-21.

Shear, Walter. "Generational Differences and the Diaspora in The Joy Luck Club. Critique 34.3 (Spring 1993): 193-99.

Tan, Amy. The Joy Luck Club. London: Random House, 1989.

Young, Mary. Mules and Dragons. Westport, Conn: Greenwood Press, 1983. 
